\title{
Effects of a fibrolytic enzyme and bacterial inoculants on the fermentation, chemical composition and aerobic stability of ensiled potato hash
}

\author{
T.F. Mutavhatsindi ${ }^{1,2 \#}$, B.D. Nkosi ${ }^{1,3}$, J.J. Baloyi ${ }^{2} \&$ T. Langa ${ }^{1}$ \\ ${ }^{1}$ Division for Animal Nutrition: Animal Production Institute, P/Bag X2, Irene, 0062, South Africa \\ ${ }^{2}$ Department of Animal Science, University of Venda, Bag X5050, Thohoyandou, 0950, South Africa \\ ${ }^{3}$ Centre for Sustainable Agriculture, University of the Free State, P.O. Box 339, Bloemfontein, 9300, South Africa
}

(Received 5 August 2017; Accepted 28 November 2017; First published online 14 December 2017)

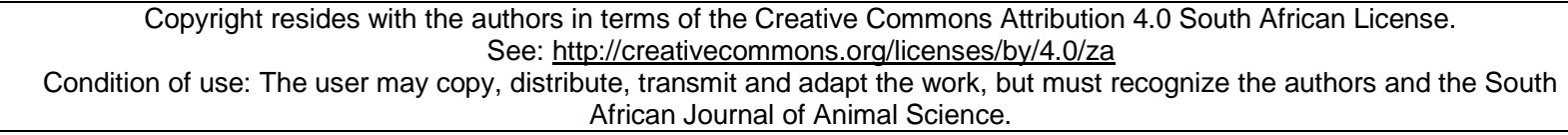

\begin{abstract}
The study was conducted to evaluate the effects of adding a fibrolytic enzyme in combination with bacterial inoculants on the fermentation, chemical composition and aerobic stability of ensiled potato hash $(\mathrm{PH})$. Potato hash silage (PHS) was produced by mixing $800 \mathrm{~g} \mathrm{PH} / \mathrm{kg}$ and $200 \mathrm{~g}$ wheat bran (WB)/kg. The mixture was ensiled with either no additive or enzyme Celluclast (low or high dose) or bacterial inoculants (Emsilage and Silosolve). These treatment combinations were produced: i) no additive (control); ii) Celluclast low dose (CLD); iii) Celluclast high dose (CHD); iv) Emsilage (EMS); v) CLD + EMS; vi) CHD + EMS; vii) Silosolve (SLS); viii) CLD + SLS; and ix) CHD + SLS. These treatments were ensiled in $81 \times 1 \mathrm{~L}$ anaerobic jars for 90 days with nine replicates per treatment. Three samples per treatment were collected before ensiling and after 90 days' ensiling, were analysed for fermentation characteristics and chemical composition. In addition, samples of day 90 were subjected to an aerobic stability test, where they were exposed for five days. Enzyme addition reduced fibre, thus making more sugar available for fermentation. The combination of $\mathrm{CHD}$ and EMS reduced silage $\mathrm{pH}$, thus preserving the silage compared with other treatment combinations. Enzyme addition (used at low and high dose), and bacterial inoculants improved fermentation. Enzyme addition improved the chemical composition, but impaired the aerobic stability of PHS. Further work to test these findings on animal performance is warranted.
\end{abstract}

Keywords: Deterioration, fibre, nutrients, $\mathrm{pH}$, ruminant, water soluble carbohydrates

\#Corresponding author: tshilifaith@gmail.com

\section{Introduction}

Agro-industrial by-products from food processing industries can be less expensive sources of nutrients for ruminant feeding because of their capacity to digest fibre-rich feedstuffs (Boucque \& Fiems, 1988). This reduces the dependency of ruminant nutrition on mixed cereals as the major energy source, which is usually costly, since cereals may have to be imported, especially in times of shortage (Briedenhann, 2008). Potato hash, a food by-product that is derived from the production of snacks in South Africa, can benefit livestock production. It is a mixture of potato skins, starch, fats and yellow maize, containing $700 \mathrm{~g} \mathrm{starch} / \mathrm{kg}$ dry matter (DM), $11.2 \mathrm{MJ}$ Metabolisable energy (ME)/kg, $105 \mathrm{~g}$ crude protein (CP) $/ \mathrm{kg}$ DM, $369 \mathrm{~g}$ Neutral detergent fibre (NDF)/kg DM, and $162 \mathrm{~g}$ Acid detergent fibre (ADF) $/ \mathrm{kg}$ DM (Nkosi et al., 2010a). The production of $\mathrm{PH}$ is estimated at 50 tons per day, and if not effectively used, is dumped.

Ensiling can be regarded as an efficient way of preserving high moisture by-products if all essential principles are followed (Cao et al., 2009). Wilkinson (2005) indicated that a content of water soluble carbohydrates (WSCs), low buffering capacity, 250-400 g DM/ $\mathrm{kg}$, and adequate population of lactic acid bacteria (LAB) are requirements for effective fermentation of forages. Potato hash, like other potato byproducts, contains low DM and WSCs (Nkosi et al., 2012a), which warrants the use of silage additives (McDonald et al., 2011). Nkosi et al. (2010b) produced silage successfully from PH by mixing with wheat bran (WB) as an absorbent and CP source or by producing a total mixed ration that contained $800 \mathrm{~g} / \mathrm{kg} \mathrm{PH}$.

Aerobic stability, defined as the number of hours it takes silage temperature to rise $2{ }^{\circ} \mathrm{C}$ above ambient temperature, is important because of the consequential losses of nutrients, and the development of moulds, which could produce mycotoxins that pose health hazards to animals and humans (Driehuis \& Oude 
Elferink, 2000). The extent of aerobic exposure can be indicated by the rate of $\mathrm{CO}_{2}$ production, a rise in temperature and $\mathrm{pH}$, and rapid growth of yeasts and moulds (Ashbell et al., 1991).

Well-preserved silages, particularly those inoculated with homofermentative LAB, can be prone to spoilage (Muck, 2010), because of lower production of VFAs that inhibit the growth of yeasts and moulds (Weinberg et al., 1993). However, the problem of aerobic stability can be solved with the use of L. buchneri, a heterolactic bacterium that converts moderate amounts of Lactic acid (LA) to Acetic acid (AA) under anaerobic conditions (Driehuis et al., 1999). Inoculants containing L. buchneri have improved the aerobic stability of various silages (Nkosi \& Meeske, 2010).

Although bacterial inoculants have been reported to improve silage fermentation and aerobic stability, their effects on fibre degradation are not consistent because LAB cannot effectively use fibre as an energy source to produce LA. Most LAB have little or no ability to degrade plant cell walls (McDonald et al., 2011). Potato hash contains $369 \mathrm{~g} \mathrm{NDF/kg} \mathrm{DM}$ and $162 \mathrm{~g} \mathrm{ADF} / \mathrm{kg}$ DM (Nkosi et al., 2010a). When mixed with other fibrous sources, the fibre content may increase, which would render $\mathrm{PH}$ silage unsuitable for growing ruminants as a sole diet or for inclusion in diets at high levels.

It has been reported that fibrolytic enzyme application at ensiling has improved the fermentation and nutritive value of maize silage (Colombatto et al., 2003), Bermuda grass silage (Dean et al., 2005) and potato pulp (Okine et al., 2005). An improvement in silage aerobic stability due to L. buchneri and enzyme combination has been reported for high moisture maize silage (Taylor et al., 2000) and barley silage (Kung \& Ranjit, 2001). However, Ebling (2002) reported that the addition of enzymes showed no further improvement in aerobic stability compared with the effect of $L$. buchneri alone in high moisture silage.

The objective of this study was therefore to determine the effects of addition of a fibrolytic enzyme and bacterial inoculants on the fermentation, chemical composition and aerobic stability of ensiled PH.

\section{Materials and Methods}

Potato hash was collected from Simba (336 Andre Greyvenstein Road, Isando, Gauteng, South Africa) and brought to Agricultural Research Council-Animal Production Institute (ARC-API) for chemical analysis and silage production. PHS was produced by mixing $800 \mathrm{~g} \mathrm{PH} / \mathrm{kg}$ with $200 \mathrm{~g} \mathrm{WB} / \mathrm{kg}$. WB, a by-product from milling of wheat, is a cheap feed ingredient that contains high DM. It was used to improve the DM content during ensiling PH (Nkosi et al., 2010a). Celluclast $\Theta^{\circledR} 1.5$ L (Novozymes, Denmark), a fibrolytic enzyme, contains cellulose prepared from Trichoderma reesei and has a stated enzyme activity of $1500 \mathrm{NCU}$ (novo cellulose units) $\mathrm{ml}^{-1}$. Celluclast was applied at a rate of $1.1 \mathrm{~L}(1 \mathrm{~L}$ water mixed with $100 \mathrm{ml}$ CLD, or $1.2 \mathrm{~L}(1 \mathrm{~L}$ water mixed with $200 \mathrm{ml}$ CHD. These doses were used to treat $500 \mathrm{~kg}$ freshly mixed material. Silosolve ${ }^{\mathrm{TM}}$ AS 200 (Chr. Hansen Inc., Animal Health and Nutrition, Czech Republic), a heterofermentative LAB inoculant, contains Lactobacillus plantarum (DSM 16568 at $2.5 \times 10^{10} \mathrm{cfu} / \mathrm{g}$ ), Enterococcus faecium (DSM 22502/ NCIMB 11181 at $3.8 \times 10^{10} \mathrm{cfu} / \mathrm{g}$ ) and Lactobacillus buchneri (DSM 22501/CCM $1819 \times 6.3 \times 10^{10} \mathrm{cfu} / \mathrm{g}$ ). Five grams of Silosolve were dissolved in $1 \mathrm{~L}$ distilled water and used to treat $500 \mathrm{~kg}$ freshly mixed material. Emsilage (Probiokashi (Pty) Ltd, Stellenbosch, South Africa), a heterofermentative LAB inoculant, contains Lactobacillus plantarum, Lactobacillus fermentum and Lactobacillus lactis. An amount of $250 \mathrm{ml}$ of Emsilage was diluted in $6.75 \mathrm{~L}$ water, and $2 \mathrm{~L}$ of this solution was used to treat $500 \mathrm{~kg}$ of freshly mixed PH. The control (untreated) silage was sprayed with $2 \mathrm{~L}$ distilled water per $500 \mathrm{~kg}$ freshly mixed material to ensure the same amount of moisture as in the treated silage.

Nine treatment combinations were produced: i) no additive (control); ii) Celluclast low dose (CLD); iii) Celluclast high dose (CHD); iv) Emsilage (EMS); v) CLD + EMS; vi) CHD + EMS; vii) Silosolve (SLS); viii) CLD + SLS; and ix) CHD + SLS. The treatments were ensiled in $81 \times 1.5 \mathrm{~L}$ anaerobic glass jars (J. Weck, $\mathrm{GmBHu}$. Co., Wehr-Oflingen, Germany) with nine jars per treatment. Each jar was filled with approximately $850 \mathrm{~g}$ (wet weight) of fresh $\mathrm{PH}$ material without head space. The jars were stored in the laboratory at a temperature of $24-28{ }^{\circ} \mathrm{C}$ to allow fermentation to occur for 90 days. Three samples per treatment were collected before ensiling and analysed for $\mathrm{pH}$, WSCs, DM, CP, Gross energy (GE), NDF and ADF. Samples of Day 90 were analysed for fermentation characteristics and chemical composition. In addition, samples of Day 90 were subjected to an aerobic stability test in which $250 \mathrm{~g}$ from each jar was loosely packed in an open plastic jar that was covered with two layers of cheesecloth and kept at $28{ }^{\circ} \mathrm{C}$. Thermocouples (T-type copper constantan, 20-gauge wire) were placed in the geometric centre of the silage mass in each jar and in the room where the jars were stored to record temperature. The room temperature and temperature in each jar were recorded simultaneously at one-hour intervals using a CR7X data logger (Campbell Scientific, Logan, Utah) for five days. The number of hours recorded by the data logger was regarded as the time taken for the silage temperature to rise $2{ }^{\circ} \mathrm{C}$ above ambient temperature. $\mathrm{CO}_{2}$ production, changes in $\mathrm{PH}$ and yeast and mould activity were determined after five days of aerobic exposure of silage using $2 \mathrm{~L}$ polyethylene terephthalate bottles according to a method described by Ashbell et al. (1991). 
A representative $40 \mathrm{~g}$ (pre-ensiled and silage) sample was taken from each jar and mixed with $360 \mathrm{ml}$ distilled water in a stomacher bag, homogenized and left at $10^{\circ} \mathrm{C}$ for 24 hours (Suzuki \& Lund, 1980). It was then homogenized for four minutes and filtered through a Whatman no. 4 filter paper (GIC Scientific, Midrand, South Africa). The $\mathrm{pH}$ was determined immediately with a $\mathrm{pH}$ meter (Thermo Orion Model 525, Thermo Fisher Scientific, Waltham, MA, USA). The filtrate was used to determine WSCs, LA, Volatile fatty acids (VFAs) and ammonia $\left(\mathrm{NH}_{3}-\mathrm{N}\right)$.

The WSC fraction was determined by the phenol-sulphuric acid method of Dubois et al., (1956). LA was determined by the colometric method of Pryce (1969). The VFAs were analysed with a Varian 3300 flame ionization detector (FID) gas chromatograph (Varian Associates, Inc., Palo Alto, CA, USA) by the procedure of Suzuki \& Lund (1980). Ammonia-N was determined according to Broderick \& Kang (1980).

The DM of silage was determined by drying the samples at $60^{\circ} \mathrm{C}$ to a constant mass and was corrected for loss of volatile fatty acids using the equation of Porter \& Murray (2001), using the equation:

True DM= $19.96+0.9793[0.987($ ODM60 - 0.260].

After drying, the samples were ground through a 1-mm screen (Wiley Mill, Standard Model 3, Arthur $\mathrm{H}$. Thomas., Philadelphia, PA, USA) for chemical analysis.

NDF and ADF content were fractionated using heat-stable a-amylase (Sigma- Aldrich Co. LTD., Gillingham, UK, no. A-1278) with sodium sulphite according to Van Soest et al. (1991) using the Fibretech system equipment (Tecator Ltd, Thornbury, Bristol, UK). CP was estimated according to AOAC (1990 ID 976.05). GE was determined with a bomb calorimeter (MS-1000 modular calorimeter, Energy Instrumentation, 135 Knoppieslaagte, Centurion, South Africa). Enumeration of yeasts and moulds was done according to the procedure of IDF (1990).

Data on the effects of treatment combinations on fermentation, chemical composition and aerobic stability of the $\mathrm{PH}$ silage were analysed for a $3 \times 3$ factorial in a completely randomised design on a general linear model using Minitab Statistical Software Release 16 (Minitab, 2010). Tukey's test was used to compare the treatment means. The model was as follows:

$$
Y_{i j k}=\mu+E_{i}+B_{j}+(E \times B)_{i j}+\varepsilon_{i j k}
$$

Where: $\mu=$ overall mean

$E_{i}=$ effect of the $i^{\text {th }}$ enzyme inoculant

$B_{j}=$ effect of the $j^{\text {th }}$ bacterial inoculant

$(E B)_{i j}=$ effect of interaction between the $i^{\text {th }}$ enzyme and $j^{\text {th }}$ bacterial inoculants

$\varepsilon_{\mathrm{ijk}}=$ residual error

\section{Results and Discussion}

The chemical composition of pre-ensiled PH with or without WB is shown in Table 1.

Table 1 Chemical composition ( $\mathrm{g} / \mathrm{kg}$ dry matter) of pre-ensiled potato hash with or without wheat bran $(\mathrm{n}=3)$

\begin{tabular}{lcc}
\hline Parameter & Potato hash & a Potato hash / wheat bran mixture \\
\hline DM g/kg & 188 & 352 \\
CP & 84.8 & 152 \\
GE & 13.9 & 16.3 \\
NDF & 500 & 449 \\
ADF & 146 & 139 \\
WSC & 3.35 & 76.0 \\
pH & 6.20 & 6.20
\end{tabular}

DM: dry matter; CP: crude protein; GE: gross energy; NDF: amylase-treated neutral detergent fibre; ADF: acid detergent fibre; WSCs: water soluble carbohydrates

${ }^{a} 80 \%$ potato hash: $20 \%$ wheat bran 
The DM of a crop at ensiling has a strong influence on the rate and extent of the resulting fermentation (McDonald et al., 2011). A low DM content with low sugar content increases the chances of clostridial fermentation and subsequent poor acceptance by animals (Fraser et al., 2000). DM content of $250-400 \mathrm{~g} / \mathrm{kg}$ in forage is required for favourable fermentation (Wilkinson, 2005). The DM of PH (188 g DM/kg) was not ideal for effective fermentation and warranted the addition of WB, increasing the DM to $352 \mathrm{~g} / \mathrm{kg}$, which is within the required range. WSCs are regarded as essential substrates for the growth of LAB to enhance efficient fermentation (McDonald et al., 2011). Lunden-Petersen \& Lindgren (1990) recommended 60-70 g $\mathrm{WSC} / \mathrm{kg}$ DM for well-preserved silage. The addition of WB to $\mathrm{PH}$ at ensiling increased WSCs to $76 \mathrm{~g}$ WSC/kg DM, making more substrate available for LAB.

Data on the fermentation characteristics of $\mathrm{PH}$ after 90 days of ensiling are presented on Table 2. The $\mathrm{pH}$, WSC, LA, AA, and PA were significantly influenced by interaction between the bacterial inoculant and the enzyme. It is documented (McDonald et al., 2011) that one of the most important factors affecting silage quality is the rate of decrease in $\mathrm{pH}$ of the plant material being preserved. A pH range of 3.7-4.2 is generally considered beneficial for forage preservation (Kung \& Shaver, 2001). That of the present study was less than 3.5 , an indication of well-preserved silage.

Table 2 Effects of enzyme and bacterial inoculants on the fermentation characteristics of potato hash after 90 days of ensiling $(n=3)$

\begin{tabular}{|c|c|c|c|c|c|c|c|c|c|c|}
\hline Treatment & Enzyme & $\begin{array}{l}\text { Bact. } \\
\text { Inoc. }\end{array}$ & $\begin{array}{c}\text { DM } \\
(\mathbf{g} / \mathbf{k g})\end{array}$ & $\mathrm{pH}$ & $\begin{array}{c}\text { WSC } \\
(\mathrm{g} / \mathbf{k g} \\
\mathrm{DM})\end{array}$ & $\begin{array}{c}\text { LA } \\
(\mathbf{g} / \mathbf{k g} \\
\mathrm{DM}) \\
\end{array}$ & $\begin{array}{c}\text { AA } \\
\text { (g/kg } \\
\text { DM) }\end{array}$ & $\begin{array}{c}\text { PA } \\
(\mathrm{g} / \mathbf{k g} \\
\mathrm{DM}) \\
\end{array}$ & $\begin{array}{c}\text { BA } \\
\text { (g/kg } \\
\text { DM) }\end{array}$ & $\begin{array}{c}\mathrm{NH}_{3}-\mathrm{N} \\
(\mathrm{g} / \mathrm{kg} \\
\mathrm{TN})\end{array}$ \\
\hline 1 & 0 & 0 & 321 & $3.51^{\mathrm{a}}$ & $12.7^{e}$ & $66.4^{\mathrm{c}}$ & $6.35^{\mathrm{ef}}$ & $1.35^{\mathrm{b}}$ & 0.13 & 4.32 \\
\hline 2 & CLD & 0 & 317 & $3.36^{\mathrm{de}}$ & $16.7^{\mathrm{bcd}}$ & $86.7^{\mathrm{a}}$ & $6.82^{\mathrm{de}}$ & $0.90^{d}$ & 0.32 & 3.74 \\
\hline 3 & $\mathrm{CHD}$ & 0 & 327 & $3.37^{\mathrm{ef}}$ & $19.5^{\mathrm{a}}$ & $84.3^{\mathrm{a}}$ & $7.44^{\mathrm{bc}}$ & $0.88^{d}$ & 0.00 & 3.65 \\
\hline 4 & 0 & EMS & 327 & $3.34^{\dagger}$ & $9.00^{f}$ & $86.2^{\mathrm{a}}$ & $7.15^{\mathrm{cd}}$ & $1.08^{\mathrm{C}}$ & 0.25 & 3.93 \\
\hline 5 & CLD & EMS & 381 & $3.42^{\mathrm{c}}$ & $15.6^{d}$ & $77.6^{\mathrm{b}}$ & $6.02^{f}$ & $0.79^{\mathrm{e}}$ & 0.00 & 3.36 \\
\hline 6 & $\mathrm{CHD}$ & EMS & 325 & $3.34^{\dagger}$ & $17.5^{\mathrm{bc}}$ & $61.5^{\mathrm{d}}$ & $6.12^{f}$ & $0.69^{\dagger}$ & 0.00 & 3.71 \\
\hline 7 & 0 & SLS & 356 & $3.45^{\mathrm{b}}$ & $12.1^{\mathrm{e}}$ & $61.9^{\text {cd }}$ & $9.64^{\mathrm{a}}$ & $1.68^{\mathrm{a}}$ & 0.28 & 4.42 \\
\hline 8 & CLD & SLS & 373 & $3.37^{d}$ & $16.2^{\mathrm{cd}}$ & $63.2^{\mathrm{cd}}$ & $7.70^{\mathrm{b}}$ & $1.70^{\mathrm{a}}$ & 0.20 & 4.43 \\
\hline 9 & $\mathrm{CHD}$ & SLS & 362 & $3.37^{d}$ & $18.0^{\mathrm{ab}}$ & $60.8^{\mathrm{d}}$ & $7.91^{\mathrm{b}}$ & $1.67^{\mathrm{a}}$ & 0.13 & 4.43 \\
\hline SEM & & & 819.5 & 0.000178 & 0.97 & 7.95 & 0.10 & 0.001 & 0.02 & 0.06 \\
\hline \multicolumn{11}{|c|}{ Enzyme means } \\
\hline 0 & & & 334 & $3.46^{\mathrm{a}}$ & $11.3^{\mathrm{C}}$ & $63.2^{b}$ & $8.24^{a}$ & $1.37^{\mathrm{a}}$ & $0.22^{\mathrm{a}}$ & $3.93^{b}$ \\
\hline CLD & & & 357 & $3.36^{\mathrm{b}}$ & $16.2^{\mathrm{b}}$ & $75.8^{\mathrm{a}}$ & $6.85^{\mathrm{b}}$ & $1.13^{\mathrm{b}}$ & $0.17^{\mathrm{ab}}$ & $3.89^{b}$ \\
\hline $\mathrm{CHD}$ & & & 345 & $3.35^{\mathrm{b}}$ & $18.3^{\mathrm{a}}$ & $77.1^{\mathrm{a}}$ & $6.64^{\mathrm{b}}$ & $1.08^{\mathrm{c}}$ & $0.04^{\mathrm{b}}$ & $4.26^{a}$ \\
\hline SEM & & & 819.5 & 0.000178 & 0.97 & 7.95 & 0.10 & 0.001 & 0.02 & 0.06 \\
\hline \multicolumn{11}{|c|}{ Bacterial inoculant means } \\
\hline 0 & & & $321^{b}$ & $3.40^{\mathrm{a}}$ & 15.1 & $79.1^{a}$ & $7.39^{b}$ & $1.04^{\mathrm{b}}$ & 0.15 & $3.75^{b}$ \\
\hline EMS & & & $351^{\mathrm{ab}}$ & $3.37^{b}$ & 15.3 & $75.1^{\mathrm{b}}$ & $6.43^{c}$ & $0.85^{\mathrm{C}}$ & 0.08 & $3.94^{b}$ \\
\hline SLS & & & $364^{\mathrm{a}}$ & $3.39^{\mathrm{a}}$ & 15.5 & $62.0^{\mathrm{C}}$ & $7.90^{\mathrm{a}}$ & $1.68^{\mathrm{a}}$ & 0.20 & $4.39^{\mathrm{a}}$ \\
\hline SEM & & & 819.5 & 0.000178 & 0.97 & 7.95 & 0.10 & 0.001 & 0.02 & 0.06 \\
\hline \multicolumn{11}{|l|}{ Significance } \\
\hline Bact. Inoc. ( & & & ** & ** & NS & ** & ** & ** & NS & ** \\
\hline Enzyme (E) & & & NS & ** & $\star \star *$ & ** & ** & ** & * & $\star \star$ \\
\hline ExB & & & NS & ** & ** & ** & ** & ** & NS & NS \\
\hline
\end{tabular}

\footnotetext{
${ }^{a-f}$ Means in the same column within the same section with different superscripts differ significantly $(P<0.05)$. CLD: Celluclast low dose; CHD: Celluclast high dose; EMS: Emsilage; SLS: Silosolve; Bact. Inoc: bacterial inoculant; DM: dry matter; TN: total nitrogen; WSCs: water soluble carbohydrates; LA: lactic acid; $\mathrm{AA}$ : acetic acid; $\mathrm{PA}$ : propionic acid; $\mathrm{BA}$ : butyric acid; $\mathrm{NH}_{3}-\mathrm{N}$ : ammonia nitrogen; NS: not significant; ${ }^{*} P<0.05$; ${ }^{* *} P<0.01$
} 
The addition of Celluclast reduced $(P<0.05)$ silage $\mathrm{pH}$ compared with other treatments. This is consistent with other reports (Nkosi et al., 2012b) in which silage $\mathrm{pH}$ was reduced with the addition of enzyme to forage (peas, ryegrass, wheat, sweet sorghum) at ensiling. However, the level of enzyme addition (CLD vs CHD) did not differ $(P>0.05)$ in the reduction of silage $\mathrm{pH}$. The reduction in $\mathrm{pH}$ due to Emsilage addition is consistent with results from another study (Pedroso et al., 2008) and could be attributed to the higher LA content observed in this silage (Table 2), typical of a homofermentative LAB inoculant pathway (Pahlow et al., 2003).

The addition of Celluclast resulted in higher $(P<0.05)$ residual WSC content of $\mathrm{PH}$ silage, indicative that more fibre fractions were degraded by enzyme addition to increase sugar content of ensiled $\mathrm{PH}$. These results are consistent with those of other studies (Nadeau et al., 2000) where enzymes were reported to increase WSC of ensiled forages. Increasing the level of enzyme application (CHD) increased $(P<0.05)$ the residual WSC content of PHS compared with CLD and the control treatments.

The increased $(P<0.05)$ LA observed in the EMS treatment $(86.2 \mathrm{~g} \mathrm{LA} / \mathrm{kg} \mathrm{DM})$ was higher than the $67.3 \mathrm{~g} \mathrm{LA} / \mathrm{kg}$ DM observed by Okine et al. (2005). This could be attributed to the differences in inoculant activities in the various studies. Increasing Celluclast application did not have a superior effect on LA production compared with the low dose, but the overall enzyme addition increased LA production compared with the control, consistent with findings of Chamberlain \& Robertson (1992).

The production of AA during silage production is a result of a heterofermentative pathway that leads to a reduction in production of aerobic microbes and increase in silage $\mathrm{pH}$ (McDonald et al., 2011). However, an increase in silage AA production leads to the inhibition of spoilage microorganisms because of its antifungal characteristics, thereby promoting aerobic stability (Danner et al., 2003). A concentration of more than $3 \mathrm{~g} \mathrm{AA} / \mathrm{kg}$ DM is enough to stabilize silage during aerobic exposure (Weissbach, 1996). The AA content in the current study ranged between 6.02 and $9.64 \mathrm{~g} \mathrm{AA} / \mathrm{kg} \mathrm{DM}$, which is higher than the AA content reported in the study by Ozduven et al. (2010). These variations could be attributed to the differences in chemical composition of the ensiled material (McDonald et al., 2011).

The treatment combinations involving Silosolve, that is. SLS + no enzyme, SLS + CLD, and SLS + CHD, had increased $(P<0.05)$ AA content compared with other treatments. However, combinations of enzyme and EMS, that is, CLD + EMS and CHD + EMS, had reduced $(P<0.05)$ AA concentration compared with other treatment combinations. Silosolve contains $L$. buchneri and therefore an increase in AA was expected (Ranjit et al., 2002). The reduced AA with Emsilage or enzyme addition is typical of homofermentative LAB, which have often reduced the aerobic stability of silages because of lower concentrations of VFAs, which inhibit the growth of yeasts and moulds (Muck \& Kung, 1997). Enzyme alone and EMS reduced $(P<0.05)$ silage PA, contributing to poor aerobic stability (Muck \& Kung, 1997).

Silage Butyric acid (BA) content indicates that it has undergone a clostridial type of fermentation, which results in the loss of energy (McDonald et al., 2011). An amount of $<0.1 \mathrm{~g} \mathrm{BA} / \mathrm{kg} \mathrm{DM}$ is typically found in well-preserved silage (Kung \& Shaver, 2001). Enzyme addition reduced $(P<0.05)$ BA content compared with control, which is consistent with the findings of Adogla-Bessa et al., (1999). Increasing the application level of CHD reduced $(P<0.05)$ silage BA concentration compared with CLD and the control. The increased $(P<0.05)$ BA concentration in control silage is associated with the increased $\mathrm{pH}$ in this silage, typical of clostridial fermentation silages (McDonald et al., 2011).

The $\mathrm{NH}_{3}-\mathrm{N}$ content in silage reflects the degree of protein degradation (Wilkinson, 2005). Wellpreserved silages should contain less than $100 \mathrm{~g} \mathrm{NH}_{3}-\mathrm{N} / \mathrm{kg} \mathrm{TN}$ (McDonald et al., 2011). The concentration of $\mathrm{NH}_{3}-\mathrm{N}$ in the present study was less than $5 \mathrm{~g} \mathrm{NH}_{3}-\mathrm{N} / \mathrm{kg}$ T. CHD reduced $(P<0.05)$ silage $\mathrm{NH}_{3}-\mathrm{N}$ and pH compared with control, indicating that less proteolysis has occurred in these silages. Silosolve contains $L$. buchneri and its inoculation increased $(P<0.05)$ silage $\mathrm{NH}_{3}-\mathrm{N}$ and $\mathrm{pH}$ compared with control, indicating that proteolysis occurred with this treatment. This study contradicts the results from other studies (Kung et al., 2007), which reported no differences in $\mathrm{NH}_{3}-\mathrm{N}$ concentration between $L$. buchneri control silages. Further research could be carried out to investigate these contradictions.

The chemical composition of PHS produced without or with a fibrolytic enzyme and bacterial inoculants is presented in Table 3. The increased $(P<0.05)$ CP concentrations in CLD and CHD compared with control were consistent with findings from Bermuda grass silages (Dean et al., 2005) and perennial ryegrass silage (Rodriguez et al., 2001). The increase in CP concentration in the CLD treatment was due to reduced $\mathrm{NH}_{3}-\mathrm{N}$ content in this treatment (Table 2). The increased $(P<0.05) \mathrm{GE}$ concentration in EMS silage could be attributed to the lower BA (Table 2) concentration in this silage.

The reduced $(P<0.05)$ fibre content with CLD and CHD silages compared with control is consistent with previous observations on enzyme-treated Bermuda grass silage (Dean et al., 2005), wheat silage (Adogla-Bessa et al., 1999), maize silage (Colombatto et al., 2004, Donmez et al., 2003), and orchard grass and alfalfa silages (Nadeau et al., 2000), perennial ryegrass silage (Rodriguez et al., 2001) and whole-plant sweet sorghum (Nkosi et al., 2012a). The reduction in fibre content (NDF and ADF) with Emsilage and 
Silosolve could be attributed to partial hydrolysis of hemicelluloses (Muck \& Kung, 1997), and is consistent with the results of Nkosi et al. (2011).

Table 3 Effects of a fibrolytic enzyme and bacterial inoculants on the chemical composition of ensiled potato hash $(n=3)$

\begin{tabular}{|c|c|c|c|c|c|c|}
\hline Treatment & Enzyme & $\begin{array}{l}\text { Bact. } \\
\text { Inoc. }\end{array}$ & $\mathrm{CP}(\mathrm{g} / \mathrm{kg} \mathrm{DM})$ & $\begin{array}{c}\text { GE (MJ/kg } \\
\text { DM }\end{array}$ & NDF (g/kg DM) & $\begin{array}{c}\text { ADF (g/kg } \\
\text { DM) }\end{array}$ \\
\hline 1 & 0 & 0 & $141^{d}$ & $16.9^{b}$ & $443^{a}$ & $151^{a}$ \\
\hline 2 & CLD & 0 & $148^{\mathrm{b}}$ & $17.0^{\mathrm{b}}$ & $343^{c}$ & $111^{\dagger}$ \\
\hline 3 & $\mathrm{CHD}$ & 0 & $151^{\mathrm{a}}$ & $17.1^{\mathrm{b}}$ & $311^{d}$ & $109^{\dagger}$ \\
\hline 4 & 0 & EMS & $143^{\mathrm{c}}$ & $17.6^{\mathrm{a}}$ & $348^{\mathrm{c}}$ & $131^{d}$ \\
\hline 5 & CLD & EMS & $147^{\mathrm{b}}$ & $17.5^{\mathrm{a}}$ & $420^{b}$ & $145^{\mathrm{c}}$ \\
\hline 6 & $\mathrm{CHD}$ & EMS & $131^{\mathrm{e}}$ & $16.0^{c}$ & $419^{b}$ & $118^{\mathrm{e}}$ \\
\hline 7 & 0 & SLS & $123^{\dagger}$ & $15.0^{d}$ & $356^{\mathrm{c}}$ & $120^{\mathrm{e}}$ \\
\hline 8 & CLD & SLS & $121^{9}$ & $14.6^{\mathrm{e}}$ & $454^{\mathrm{a}}$ & $148^{\mathrm{ab}}$ \\
\hline 9 & $\mathrm{CHD}$ & SLS & $120^{9}$ & $13.7^{\dagger}$ & $412^{\mathrm{b}}$ & $148^{\mathrm{ab}}$ \\
\hline SEM & & & 0.93 & 0.03 & 89.0 & 3.25 \\
\hline \multicolumn{7}{|c|}{ Enzyme means } \\
\hline 0 & & & $135^{\mathrm{b}}$ & $16.5^{\mathrm{a}}$ & $406^{\mathrm{a}}$ & $133^{\mathrm{a}}$ \\
\hline CLD & & & $139^{a}$ & $16.4^{\mathrm{a}}$ & $406^{a}$ & $135^{\mathrm{a}}$ \\
\hline $\mathrm{CHD}$ & & & $134^{\mathrm{C}}$ & $15.6^{\mathrm{b}}$ & $357^{\mathrm{b}}$ & $125^{\mathrm{b}}$ \\
\hline SEM & & & 0.93 & 0.03 & 89.0 & 3.25 \\
\hline \multicolumn{7}{|c|}{ Bacterial inoculant means } \\
\hline 0 & & & $147^{\mathrm{a}}$ & $17.0^{\mathrm{a}}$ & $436^{\mathrm{a}}$ & $143^{\mathrm{a}}$ \\
\hline EMS & & & $140^{\mathrm{b}}$ & $17.0^{\mathrm{a}}$ & $396^{\mathrm{b}}$ & $137^{b}$ \\
\hline SLS & & & $121^{\mathrm{c}}$ & $14.4^{\mathrm{b}}$ & $337^{\mathrm{c}}$ & $113^{c}$ \\
\hline SEM & & & 0.93 & 0.025 & 89.0 & 3.25 \\
\hline \multicolumn{7}{|l|}{ Significance } \\
\hline Bact. Inoc. (B) & & & ** & ** & ** & ** \\
\hline Enzyme (E) & & & ** & ** & ** & $* *$ \\
\hline ExB & & & ** & ** & ** & ** \\
\hline
\end{tabular}

\footnotetext{
${ }^{a-t}$ Means in the same column within a section with different superscripts differ significantly $(P<0.05)$. CLD: Celluclast low dose; CHD: Celluclast high dose; EMS: Emsilage; SLS: Silosolve; Bact. Inoc.: Bacterial inoculant; DM: Dry matter; CP: Crude protein; GE: Gross energy; NDF: Neutral detergent fibre; ADF: Acid detergent fibre. ${ }^{\star \star} P<0.01$
}

Data on the aerobic stability of PHS treated without or with additives (fibrolytic enzyme and bacterial inoculants) are presented in Table 4. Aerobic deterioration of silage is a complex process and is usually initiated by aerobic yeasts that use residual WSCs or LA for their metabolism. After exposure to air for five days, silages treated with Silosolve (SLS, CLD + SLS, and CHD + SLS) showed improved $(P<0.05)$ aerobic stability, as indicated by the increased $(P<0.05)$ number of hours they remained stable, their low $\mathrm{pH}$, and their reduced $(P<0.05) \mathrm{CO}_{2}$ and yeast and mould population compared with other silages. These results are consistent with those of Nkosi et al. (2012b), who reported improved aerobic stability with a heterofermentative LAB + enzyme addition in sweet sorghum silage. Addition of enzyme, alone or in combination with Emsilage, impaired the aerobic stability of silage, as indicated by higher $(P<0.05) \mathrm{pH}, \mathrm{CO}_{2}$ production, and yeast and mould population counts, and reduced $(P<0.05)$ the number of hours compared with silages treated with Silosolve LAB inoculant. These results were inconsistent with those of Chen et al. (1994), who reported reduced aerobic stability owing to enzyme-inoculant addition to maize silage. 
Table 4 Effects of a fibrolytic enzyme and bacterial inoculants on the aerobic stability of potato hash silage ( $\mathrm{n}$ $=3)$

\begin{tabular}{|c|c|c|c|c|c|c|}
\hline Treatment & Enzyme & Bact. Inoc. & $\mathrm{pH}$ & $\mathrm{CO}_{2}(\mathrm{~g} / \mathrm{kg} \mathrm{DM})$ & Hrs & Yeast \& Moulds \\
\hline 1 & 0 & 0 & $7.07^{\mathrm{C}}$ & $15.5^{\mathrm{e}}$ & $63.5^{\mathrm{d}}$ & $3 \times 10^{5 b c}$ \\
\hline 2 & CLD & 0 & $8.14^{\mathrm{b}}$ & $29.3^{\mathrm{b}}$ & $57.9^{e}$ & $3 \times 10^{7 a}$ \\
\hline 3 & $\mathrm{CHD}$ & 0 & $8.90^{\mathrm{a}}$ & $31.5^{\mathrm{a}}$ & $55.1^{\mathrm{e}}$ & $3 \times 10^{7 a}$ \\
\hline 4 & 0 & EMS & $8.23^{\mathrm{b}}$ & $18.9^{d}$ & $66.1^{\mathrm{cd}}$ & $3 \times 10^{5 b c}$ \\
\hline 5 & CLD & EMS & $7.30^{\mathrm{c}}$ & $11.0^{\mathrm{g}}$ & $76.2^{\mathrm{b}}$ & $7 \times 10^{5 b}$ \\
\hline 6 & $\mathrm{CHD}$ & EMS & $7.44^{\circ}$ & $26.5^{\mathrm{c}}$ & $66.5^{\mathrm{c}}$ & $3 \times 10^{7 a}$ \\
\hline 7 & 0 & SLS & $5.31^{d}$ & $8.43^{\mathrm{h}}$ & $88.7^{\mathrm{a}}$ & $2 \times 10^{c}$ \\
\hline 8 & CLD & SLS & $7.27^{\mathrm{c}}$ & $11.0^{\mathrm{g}}$ & $89.0^{\mathrm{a}}$ & $2 \times 10^{C}$ \\
\hline 9 & $\mathrm{CHD}$ & SLS & $7.12^{\mathrm{c}}$ & $12.9^{f}$ & $88.2^{\mathrm{a}}$ & $4 \times 10^{c}$ \\
\hline SEM & & & 0.08 & 0.78 & 2.87 & $7 \times 10^{10}$ \\
\hline \multicolumn{7}{|c|}{ Enzyme means } \\
\hline 0 & & & $7.46^{\mathrm{b}}$ & $15.3^{\mathrm{c}}$ & $80.2^{\mathrm{a}}$ & $1 \times 10^{7 b}$ \\
\hline CLD & & & $6.62^{\mathrm{c}}$ & $17.7^{\mathrm{b}}$ & $74.4^{\mathrm{b}}$ & $2 \times 10^{7 a}$ \\
\hline $\mathrm{CHD}$ & & & $8.19^{\mathrm{a}}$ & $22.0^{\mathrm{a}}$ & $62.6^{c}$ & $2 \times 10^{5 c}$ \\
\hline SEM & & & 0.08 & 0.78 & 2.87 & $7 \times 10^{10}$ \\
\hline \multicolumn{7}{|c|}{ Bacterial inoculant means } \\
\hline 0 & & & 7.44 & $29.1^{\mathrm{a}}$ & $58.9^{c}$ & $1 \times 10^{5 c}$ \\
\hline EMS & & & 7.30 & $12.8^{\mathrm{b}}$ & $77.0^{\mathrm{b}}$ & $1 \times 10^{7 b}$ \\
\hline SLS & & & 7.44 & $13.1^{\mathrm{b}}$ & $81.3^{\mathrm{a}}$ & $2 \times 10^{7 a}$ \\
\hline SEM & & & 0.08 & 0.78 & 2.87 & $7 \times 10^{10}$ \\
\hline \multicolumn{7}{|l|}{ Significance } \\
\hline Enzyme (E) & & & $* \star$ & ** & ** & ** \\
\hline Bact. Inoc.(B) & & & NS & ** & $* *$ & $* *$ \\
\hline ExB & & & ** & ** & ** & ** \\
\hline
\end{tabular}

\footnotetext{
${ }^{2-1}$ Means in the same column within a section with different superscripts differ significantly $(P<0.05)$.CLD: Celluclast low dose; CHD: Celluclast high dose; EMS: Emsilage; SLS: Silosolve; Bact. Inoc.: Bacterial inoculant; DM: Dry matter; $\mathrm{CO}_{2}$ : Carbon dioxide; Hrs: Hours; NS: not significant; ${ }^{* \star} P<0.01$
}

\section{Conclusions}

Silages treated with a high dose of the enzyme had lower fibre content than the untreated silages, indicating effective fibre degradation. However, enzyme inoculation, used at low and high doses, increased the WSC content. Thus, it provided more substrate for the LAB, increased LA, and reduced the pH of PHS. Although enzyme addition improved fermentation, this resulted in silages of low aerobic stability owing to increased residual sugar content. Inoculation with $L A B$ inoculants improved the fermentation process. However, this effect was more prominent for the homofermentative LAB inoculant, which is typical of these inoculants. Further work needs to be done to elucidate the effects of these silage additives on animal performance.

\section{Acknowledgements}

Financial support for this research was from Agricultural Research Council (ARC) Professional Development Program (PDP) and University of Venda Research Grant. The authors thank ARC for the laboratory analysis of the samples. Authors would also like to acknowledge Ms C. Ngwane (ARC-Biometrics) for help with the statistical analyses of the data. The Small Ruminant Nutrition Research team of the API is also acknowledged for its role in the production of silage for this project.

\section{Authors' contributions}

TFM, BDN and JJB were in charge of project design and writing of the manuscript. TFM and TL were in charge of project implementation. All co-authors participated in results, statistics and interpretation of the study. 


\section{Conflict of interest declaration}

We wish to confirm that there are no known conflict of interest associated with the publication of this manuscript and there has been no significant financial support for this work that could have influenced its outcome. We also confirm that this manuscript has been read and approved by all authors and that the order of authors listed in the manuscript has been approved by all of us.

\section{References}

Adogla-Bessa, T., Owen, E. \& Adesogan, A.T., 1999. Ensiling of whole crop wheat with cellulase-hemicellulose based enzymes. 3. Comparing effects of urea or enzyme treatment on forage composition and stability. Anim. Feed. Sci. Technol. 82, 51-61.

AOAC, 1990. Official methods of analysis. 15th edition. Association of Official Analytical Chemists. Washington DC, USA.

Ashbell, G., Weinberg, Z.G., Azriel, A., Hen, Y. \& Horev, B., 1991. A simple system to study the aerobic deterioration of silages. Ca. Agric. Eng. 33, 391-393.

Boucque, C.H.V. \& Fiems, L.O., 1988. Vegetable by-products of agro-industrial origin. Livest. Prod. Sci. 19, 97-135.

Briedenhann, E., 2008. Global and South African raw material prices: The effect on the livestock and animal feed industry. Pluimvee Poult. Bull. 4, 236.

Broderick, G.A., \& Kang, J.H., 1980. Automated simultaneous determination of ammonia and total amino acids in ruminal fluid and in vitro media. J. Dairy Sci. 63, 64-75.

Cao, Y., Takahashi, T. \& Horiguchi, K., 2009. Effects of addition of food by-products on the fermentation quality of a total mixed ration with whole crop rice and its digestibility, preference, and rumen fermentation in sheep. Anim. Feed Sci. Technol. 151,1-11.

Chamberlain, D.G. \& Robertson S., 1992. The effects of addition of various enzyme mixtures on the fermentation of perennial ryegrass silage and on its nutritional value for milk production in dairy cows. Anim. Feed Sci. Technol. 37,257

Chen, J., Stokes, M.R. \& Wallace, C.R., 1994. Effects of enzyme-inoculant systems on preservation and nutritive value of hay crop and corn silages. J. Dairy Sci. 77, 501-512.

Colombatto, D., Mould, F.L., Bhat, M.K., Phipps, R.H. \& Owens, E., 2004. In vitro evaluation of fibrolytic enzymes as additives for maize (Zea mays L.) Silage I. Effects of ensiling temperature, enzyme source and addition level. Anim. Feed Sci. Technol. 111, 111-128.

Colombatto, D., Mould, F.L., Bhat, M.K., Morgavi, D.P., Beauchemin, K.A. \& Owen, E., 2003. Influence of fibrolytic enzymes on the hydrolysis and fermentation of pure cellulose and xylan by mixed ruminal microorganisms in vitro. J. Anim. Sci. 81, 1040-1050.

Danner, H., Holzer, M., Maryhuber, E. \& Braun, R., 2003. Acetic acid increases stability of silage under aerobic conditions. Appl. Environ. Microbiol. 69, 562-567.

Dean, D.B., Adesogan, A.T., Krueger, N. \& Littell, R.C., 2005. Effect of fibrolytic enzymes on the fermentation characteristics, aerobic stability, and digestibility of Bermuda grass silage. J. Dairy Sci. 88 (Issue 3), 994-1003.

Donmez, N., Karsli, M.A., Cinar, A., Aksu, T. \& Baytok, E., 2003. The effects of different silage additives on rumen protozoan number and volatile fatty acid concentration in sheep fed corn silage. Small. Rumin. Res. 48, $227-231$.

Driehuis, F. \& Oude Elferink, S.J.W.H., 2000. The impact of the quality of silage on animal health and food safety. A review. Vet. Q. 22, 212-216.

Dubois, M., Giles, K.A., Hamilton, J.K., Rebes, P.A. \& Smith, F., 1956. Colorimetric method for determination of sugars and related substances. Anal. Chem. 28, 250-356.

Ebling, T.L., 2002. The effect of adding Lactobacillus buchneri 40788 (LB), enzymes (ENZ), or ENZ and LB on the fermentation and aerobic stability of high moisture corn in lab silos. J. Dairy. Sci. 85 (suppl.1), 383.

Fraser, M.D., Fychan, R. \& Jones, R., 2000. Voluntary intake, digestibility and nitrogen utilization by sheep fed ensiled forage legumes. Grass Forage Sci. 55, 271-279.

IDF (International Dairy Federation) 1990. International Standard 94B: Milk and Milk products-enumeration of yeasts and moulds. Colony count technique at $30^{\circ} \mathrm{C}$. IDF, Brussels, Belgium.

Kung Jr, L., \& Ranjit, N. (2001). The effect of Lactobacillus buchneri and other additives on the fermentation and aerobic stability of barley silage. J. Dairy Sci. 84:1149-1155

Kung, L., Jr. \& Shaver, R., 2001. Interpretation and use of silage fermentation analysis reports. Focus on Forage 3 (12), $1-5$.

Kung, L, Jr., Schmidt, R.J., Ebling, T.E. \& Hu, W., 2007. The effect of Lactobacillus buchneri 40788 on the fermentation and aerobic stability of ground and whole high moisture corn. J. Dairy Sci. 90, 2309-2314.

Lunden-Petterson, K. \& Lindgren, S., 1990. The influence of carbohydrate fraction and additives on silage quality. Grass Forage Sci. 45, 223-233.

McDonald, P., Edwards, R.A., Greenhalgh, J.F.D., Morgan, C.A., Sinclair, L.A. \& Wilkinson, R.G., 2011. Animal Nutrition. 7th edition. Prentice Hall Pearson, Harlow, England.

Minitab, 2010. Minitab 16 statistical software. Minitab Inc., State College, Pennsylvania, USA.

Muck, R.E., 2010. Silage additives and management issues. Proceedings of Idaho Alfalfa Forage Conference, Best Western Burley, Idaho, USA. 16-17 February 2010. Pp. 49-55.

Muck, R.E., \& Kung Jr. L., 1997. Effects of silage additives on ensiling. In: Silage: Field to Feedbunk. NRAES-99, Ithaca, NY, USA. Pp. 187-199. 
Nadeau, E.M.G., Buxton, D.R., Russell, J.R., Allison, M.J. \& Young, J.W., 2000. Enzyme bacterial inoculant and formic acid effects on silage composition of orchard grass and alfalfa. J. Dairy Sci. 83 (7), 1487-1502.

Nkosi, B.D. \& Meeske, R. 2010. Effects of ensiling totally mixed potato hash ration with or without heterofermentative bacterial inoculant on silage fermentation, aerobic stability, and growth performance of lambs. Anim. Feed Sci. Technol. 161, 38-48.

Nkosi, B.D., Meeske, R., Van der Merwe, H.J. \& Groenewald, I.B., 2010a. Effects of homofermentative and heterofermentative bacterial silage inoculants on potato hash silage fermentation and digestibility in rams. Anim. Feed Sci. Technol. 157, 195-200.

Nkosi, B.D., Meeske, R. \& Groenewald, I.B., 2010b. Effects of ensiling potato hash with either whey or sugarcane molasses on silage quality and nutrient digestibility in sheep. Livest. Res. Rural Dev. 22(1).

Nkosi, B.D., Meeske, R., Langa, T. \& Thomas, R.S., 2011. Effects of bacterial silage inoculants on whole-crop maize silage fermentation and silage digestibility in rams. S. Afr. J. Anim. Sci. 41 (4), 350-359.

Nkosi, B.D., Groenewald, I.B., Meeske, R. \& Van der Merwe, H.J., 2012a. Laboratory evaluation of absorbents and additives on the fermentation quality of potato hash. Afr. J. Agric. Res. 7 (40), 5506-5517.

Nkosi, B.D., Vandlani, P.V., Brijwani, K., Nanjunda, A. \& Meeske, R., 2012b. Effects of bacterial inoculants and an enzyme on the fermentation quality and aerobic stability of ensiled whole-crop sweet sorghum. S.Afr. J. Anim. Sci. 42 (no.3), 232-240.

Okine, A., Hanada, M., Aibibula, Y., \& Okamoto, M., 2005. Ensiling of potato pulp with or without bacterial inoculants and its effect on fermentation quality, nutrient composition and nutritive value. Anim. Feed Sci. technol. 121, 329-343.

Ozduzen, M.L., Onal, Z.K. \& Koc, F., 2010. The effects of bacterial inoculants and/or enzymes on the fermentation, aerobic stability and in vitro dry and organic matter digestibility characteristics of triticale silages. Kafkas Univ. Vet. Fak. Derg. 16 (5), 751-756.

Pahlow, G., Muck, R.E., Driehuis, F., Oude-Elferink, S.J.H. \& Spoelstra, S.F., 2003. Microbiology of ensiling. Silage science and Technology (pp. 31-93). Agronomy Monograph no. 42.

Pedroso, A.F., Nussio, L.G., Loures, D.R.S., Paziani, S.F., Ribeiro, J.L., Mari, L.J., Zopollatto, M., Schmidt, P., Mattos, W.R.S. \& Horri, J., 2008. Fermentation, losses and aerobic stability of sugarcane silages treated with chemical or bacterial additives. Sci. Agric. 65, 589-594.

Porter, M.G. \& Murray, R.S., 2001. The volatility of components of grass silage on oven drying and the inter-relationship between dry matter content estimated by different analytical methods. Grass forage Sci. 56, 405-411.

Pryce, J.D., 1969. Modification of the Barker \& Summerson method for determination of lactic acid. Analyst. 94, 11511152.

Ranjit, N.K., Taylor, C.C. \& Kung, L, Jr., 2002. Effect of Lactobacillus buchneri 40788 on the fermentation, aerobic stability and nutritive value of maize silages. Grass Forage Sci. 57, 73-81.

Rodriguez, M.A.M., Cone, J.W. \& Sequeira, C.A. \& Mascarenhas-Ferreira, A., 2001. Effect of the addition of cell wall degrading enzymes on fermentation kinetics of perennial ryegrass silage. J. Agric. Sci. 136, 443-449.

Suzuki, M. \& Lund, C.W., 1980. Improved gas liquid chromatography for simultaneous determination of volatile fatty acids and lactic acid in silage. J. Agric. Food Chem. 28, 1040-1041.

Taylor, F., Kurantz, M.J., Goldberg, N., McAloon, M.J. \& Craig Jr., J.C., 2000. Dry grind process for fuel ethanol by continuous fermentation and shipping. Biotechnol. Prog. 16, 541-547.

Van Soest, P.J., Robertson, J.B. \& Lewis, B.A., 1991. Methods of dietary fibre, neutral detergent fibre, and non-starch polysaccharides in relation to animal nutrition. J. Dairy Sci. 74, 3583-3597.

Weinberg, Z.G., Ashbell, G., Hen, Y., and Azriel, A. (1993). The effect of applying lactic acid bacteria on the aerobic stability of silages. J. Appl. Bacteriol. 75:512-518.

Weissbach, F., 1996. New development in crop conversion. In: Proceedings of the XIth International Silage Conference, Aberyswyth, UK, and pp. 11-25.

Wilkinson, J.M., 2005. Silage. Chapter 19: Analysis and clinical assessment of silage. Chalcombe, Southampton, UK. 